\title{
ACTIVITIES AND POPULARIZATION ACTIVITIES IN THE FIELD OF TECHNICAL EDUCATION IN THE CONTEXT OF HIGH SCHOOLS (AGE 15) SELECTION
}

\author{
Jarmila HONZÍKOVÁ, Západočeská univerzita v Plzni \\ Jan FADRHONC*, Západočeská univerzita v Plzni
}

Přijato: 9. 6. 2019 / Akceptováno: 23. 7. 2019

Typ článku: Výzkumný článek

DOI: $10.5507 /$ jtie.2019.006

Abstract: The presented article deals with the level and the character of popularization of technical fields and its influence on pupils of elementary schools while choosing their career. The current situation of technical education popularization was analyzed by the research survey on different levels - from the point of view of schools, regions and the state. Subsequently, the questionnaire survey of elementary school pupils revealed the extent of popularization activities influence on the interest of pupils (15 years old) in the last year of elementary schools in technical field studies at high schools.

Key words: popularization of technical fields, pupils, elementary schools, career.

\section{AKTIVITY A POPULARIZAČNÍ ČINNOST V OBLASTI TECHNICKÉHO VZDĚLÁVANÍ V KONTEXTU VÝBĚRU OBORU STŘEDNÍ ŠKOLY}

Abstrakt: Předložený článek se zabývá úrovní a charakterem popularizace technických oborů a jejím vlivem na žáky základních škol při volbě povolání. Výzkumným šetřením byl zanalyzován současný stav popularizace technického vzdělávání na riozných úrovnich - ze strany škol, krajů a státu. Dotazníkové šetření u žákù základnich škol následně odhalilo, jak popularizační aktivity ovlivňuji zájem žáků posledních ročníků ZŠ o studium technických oborů na střední škole.

Klíčová slova: popularizace technických oborů, žáci, základní škola, povolání.

*Autor pro korespondenci: fadrhonc@kvd.zcu.cz 


\section{1 Úvod}

Lidé chybějí ve stavebnictví, nejsou ani technici, strojaři, svářeči, kováři, skladníci, sociální pracovníci, zdravotnický personál... Žáci bud' nemají o přípravu na tato povolání vůbec zájem, nebo vzdělání nedokončí, př́ípadně si najdou práci mimo obor. Jak je ale motivovat $\mathrm{k}$ vyššímu zájmu o technické obory?

Firmy, které na pracovním trhu marně shánějí kvalifikované řemeslníky a techniky, zkoušejí motivovat žáky tak, aby po ukončení školy nastoupili právě k nim, např̀. stipendiem, př́ispěvky na stravování, ubytování aj. Až do výše 5 000,- Kč měsíčně jsou podobné motivační příspěvky daňově uznatelným nákladem, pokud se žák smluvně zaváže, že se bude připravovat na výkon profese právě pro tohoto zaměstnavatele. Ministerstvo školství doporučuje, aby takový závazek činili žáci až po dosažení zletilosti, leckde však firmy lákají už patnáctileté a do smluvního vztahu pro jistotu zapojují i rodiče.

Správa železniční dopravní cesty (SŽDC) např́klad nabízí stipendijní program „NádraŽák“, v jehož rámci poskytuje pravidelný příspěvek až do výše 2000 Kč měsíčně a po ukončení školy počítá $\mathrm{s}$ absolventem na místo odpovídající jeho kvalifikaci. Podmínkou je studijní průměr do 2,5 za každé pololetí, minimálně $70 \%$ účast ve výuce a řádné omluvené absence. Motivačním stipendiem ve výši 2000 Kč, resp. 4000 Kč měsíčně se snaží přilákat budoucí absolventy oborů zdravotnický asistent i Krajská zdravotní, a.s., v Ústí nad Labem (NUV, 2015).

\section{Popularizace technického vzdělávání}

V této části se seznámíme $\mathrm{s}$ koncepcí projektů na podporu technického vzdělávání v kontextu minulých let. Objevila se celá řada pobídek z krajů, které nabízí i finanční motivaci, každý kraj ale $\mathrm{k}$ tomuto problému přistupuje individuálně a není vytvořena žádná ucelená koncepce. Což je ale z části podmíněno jinou potřebou pracovníků v těchto oborech.

\subsection{Finanční pobidky z krajů}

$\mathrm{K}$ finančním pobídkám pro žáky ve vybraných oborech se připojují i některé kraje. V Plzeňském kraji například plánují finančně podpořit ty, kteří se na odborných školách připravující pro zemědělské profese. Cílem je zastavit vylidňování odlehlejších oblastí regionu a útěk mladých do měst. V Ústeckém kraji si na motivační stipendium sáhnou žáci řady oborů od čalouníků přes řezníky a uzenáře, zedníky, obráběče kovů či elektrikáře už od prvního ročníku. Podmínkou je mít v kraji trvalé bydliště, chodit do školy (min. 50\% účast bez neomluvených absencí) a nemít ředitelskou důtku či sníženou známku z chování. Liberecký kraj, Vysočina i Praha vyplácejí podobná stipendia budoucím technikům a řemeslníkům. Ve Středočeském kraji se podpora stipendijních programů v oborech poptávaných trhem práce objevuje i v Krajském akčním plánu rozvoje vzdělávání jako jeden z prvků sloužících k propagaci odborného vzdělávání a zvýšení motivace žáků o technické a řemeslné obory.

Olomoucký kraj zavedl od školního roku 2014/15 nový stipendijní program, jehož cílem je podpořit žáky technických oborů vzdělání zakončených maturitní zkouškou, o které je na trhu práce dlouhodobý zájem. Podpora technických oborů vzdělání vychází ze základního strategického dokumentu pro oblast školství Dlouhodobého záměru vzdělávání a rozvoje vzdělávací soustavy Olomouckého kraje a programového prohlášení Rady Olomouckého kraje. Olomoucký kraj se v něm zavázal podporovat aktivity vedoucí ke zvýšení počtu žáků v technických oborech vzdělání zakončených maturitní zkouškou 
a perspektivních na trhu práce. Stipendia budou poskytována žákům středních škol všech zřizovatelů, které nabízejí podporované obory vzdělání. Žáci a školy musí splňovat kritéria, která jsou daná Pravidly pro poskytování stipendia žákům technických oborů vzdělání zakončených maturitní zkouškou. Hlavním kritériem pro obdržení stipendia je, že žák nesmí mít za př́slušné pololetí školního roku horší studijní průměr než 1,70 včetně (Olomoucký kraj, 2015).

Na nedostatek absolventů technických oborů upozorňuje mimo jiných i Technologická iniciativa Plzeň, která sdružuje významné zaměstnavatele na Domažlicku nebo na Plzeňsku. Technologická iniciativa Plzeň proto ve spolupráci s podobným sdružením zaměstnavatelů TEO, které působí na Tachovsku, vypracovala devatero doporučení pro firmy s názvem Technika má zlaté dno. (Bartošová \& Milota, 2013)

\subsection{Jen penize nestači}

Jednotlivé kraje ale počítají i s jinými motivátory, což odpovídá současným poznatkům psychologie práce. Peníze totiž nejsou automaticky vždycky tím nejdůležitějším. Průzkumy ve firmách opakovaně prokazují, že zaměstnancům jde v první řadě o uznání a zapojení emocí. Peníze uvádějí až na dalších místech. V jednotlivých krajských akčních plánech (KAP), které vznikaly za metodické podpory Národního ústavu pro vzdělávání (projekt Podpora krajského akčního plánování - P-KAP) se objevuje řada dalších návrhů, jak zatraktivnit obory, v nichž chybějí lidé (Dostál, 2018). „Nechat žákům ochutnat techniku, nabízet jim přiměřeně vysoké individuální cíle, umožnit jim vidět výsledky své práce a pocítit, že dělají něco užitečného, co druzí ocení,“ považuje za důležité ředitelka Minaříková. A není sama - např́íklad tvůrci KAP v Moravskoslezském kraji vidí jako významný úkol snižovat bariéry mezi školou a prací a podpořit produktivní činnost žáků v rámci praktické části jejich odborné prrípravy. Základním předpokladem je samozřejmě úzká spolupráce škol s firmami. V akčním plánu Pardubického kraje se počitá s tím, že ve školách bude fungovat koordinátor spolupráce s firmami (Pešková, 2015; Pokorný, 2019).

\section{3 Čas pro kariérové poradenství}

Královéhradecký, Jihomoravský, Zlínský či Moravskoslezský kraj vidí jako prioritu svého krajského akčního plánu rozvoj komplexně pojatého kariérového poradenství. Mělo by podpořit zájem o potřebné obory, zprostředkovávat aktuální informace o trhu práce, mapovat předpoklady a zájmy žáků, a to i díky prítomnosti kariérového poradce ve škole. Dále umožnit studentům a učňům vlastní zkušenost s různými profesemi, práci s novou technikou ve firmách atd. Zlínský kraj plánuje rozširirit krajský vzdělávací portál Zkola.cz o modul zaměřený na svět práce a zaměstnavatele $\mathrm{v}$ regionu. S novým webovým portálem zaměřeným na propagaci odborného vzdělávání počítá i KAP středočeský. Patrný je zájem krajů zlepšit image oborů ukončených výučním listem. Ve spolupráci s partnery (od zaměstnavatelských svazů přes firmy, úřady práce až po školy samotné) chtějí měnit pohled na manuální práci například medializací inspirativních regionálních př́kladů $\mathrm{z}$ praxe, prostřednictvím propagačních filmů, které budou $\mathrm{k}$ dispozici základním školám. V komunikaci těchto záměrů nechybějí ani sociální sítě, billboardy či celokrajské veletrhy odborných škol. Jako důležitý trend se rýsuje užší spolupráce středních škol se základními, zejména tam, kde jde o propagaci technických a řemeslných oborů. V Praze například počítají s projekty na sdílení středoškolských dílen s žáky ZŠ, podobně uvažují i tvưrci KAP v Libereckém kraji. V Jihomoravském kraji hovoří o možnosti využít středoškolské 
kariérové poradce i $\mathrm{k}$ individuálnímu poradenství pro volbu povolání pro žáky vy̌šśích ročníků základních škol a jejich rodiče (Návratová, n.d.; MŠMT, 2013).

Díky aktivitám firem, krajů i škol by $\mathrm{v}$ dohledné budoucnosti mohlo ubývat prŕpadů „špatně“ zvoleného oboru, žáků, kteří školu předčasně opustí nebo se po získání kvalifikace ke své profesi nevrátí (NÚV, 2015; Pokorný, 2019).

\section{Aktivity škol a institucí v oblasti technického vzdělávání}

Podpora technického vzdělávání probíhá skrze celou řadu aktivit. Některé aktivity jsou zaměřeny víceméně na seznámení $\mathrm{s}$ technikou, kdy se $\mathrm{v}$ rámci několika dnů pořádají přednášky, př́ípadně workshopy. Jiné akce jdou více do hloubky, nabízí velké množství kurzů, kde si děti vyzkouší celou řadu technicky zaměřených aplikací, činností či zařízení. Iniciátorem jsou nejen vysoké a střední školy, ale i další vzdělávací instituce či média.

\subsection{Aktivity vysokých škol}

Ze strany vysokých škol se můžeme setkat s mnoha akcemi. Na většině z nich se též podílí Plzeňský kraj ve spolupráci se Západočeskou univerzitou. Mezi nejpopulárnější patř́ Dny vědy a techniky ZČU. Pořadatelé z různých fakult a kateder zde připravují různé výstavy, workshopy a jiné aktivity. Oblíbená je též Dětská univerzita, kde mají žáci základních škol možnost seznámit se nejen s univerzitním prostředím, ale i se spoustou zájmových činností, mezi které patř́i i ty technický zaměřené. Dále je třeba zmínit i další aktivity jako Noc vědců, rukodělnou soutěž Řemeslo má zlaté dno (RegionPlzen.cz, 2013), Olympiáda techniky.

\subsection{Aktivity střednich škol}

Střední školy se snaží získat zájemce o studium různými způsoby. Některé střední školy zavedly prospěchová stipendia učňovských a nedostatkových profesí, jiné např̀. dostávají od Plzeňského kraje v rámci podpory technického vzdělávání mládeže hmotnou podporu a finanční podporu. V Plzeňském kraji dostává každoročně devatenáct středních škol, které vzdělávají žáky ve tříletém technickém oboru, pro každého žáka 1. ročníku sadu ručního nářadí. Zajímavý byl i rok 2015, který byl vyhlášen „Rokem technického vzdělávání". Školy, které se do projektu zapojily, uspořádaly dny otevřených dveří pro děti i jejich rodiče.

Ani jiné kraje České republiky nezůstávají pozadu. Např. v Moravskoslezském kraji se klade důraz na to, aby nedocházelo k uzavírání technických oborů (Návratová, n.d.). Byly zavedeny jednotné přijímací zkoušky do všech maturitních oborů ve školách zřizovaných krajem a dochází ke snižování počtu otevíraných tříd ve středních školách zřizovaných krajem $\mathrm{v}$ oborech, které nejsou prioritně podporovány. Také podporuje málopočetné třídy s obory požadovanými trhem práce. V Pardubickém kraji byla zavedena prospěchová stipendia učňovských a nedostatkových profesí. Kraj má navázanou také úzkou spolupráci s Hospodářskou komorou, tripartitou, zástupci odborných svazů a cechů, Úřadem práce a dalšími sociálními partnery. Na základě zpracované analýzy pak plánuje další optimalizační kroky, mezi něž patří např. úzká spolupráce škol se zaměstnavateli. Velmi silný propagační a motivační efekt měl i regionální projekt Technohrátky. 


\subsection{Aktivity ostatnich institucí}

Mnoho akcí pořádají též vzdělávací instituce, jako jsou Techmania Science Center Plzeň, DEPO 2015 či Centrum robotiky. Centrum robotiky má za cíl podpořit zájem dětí o polytechnické a prírodovědné vzdělávání formou volnočasových aktivit (Centrum robotiky, 2018). Zajímavou aktivitou Národního technického muzea (Kopecký, 2007) je projekt „V technice je budoucnost" zacílený na žáky 8. a 9. tř́́d základních škol Středočeského kraje. Formou zajímavých exkurzí, e-learningu a workshopů má žákům předložit nabídku technických a řemeslných oborù. Žáci tak mohou vstoupit do virtuálního prostředí, nechat se provést vývojem daného oboru, plnit řadu úkolů, zábavnou formou získat nové vědomosti a doplnit znalosti ze školy.

\subsection{Podpora technických oborů médii}

$\mathrm{K}$ popularizaci technických oborů a zvyšování zájmu o techniku přispívají také mediální pořady $\mathrm{v}$ televizi a rozhlase, např. Bořiči mýtů, Věda je zábava, Věda je detektivka, Věda na vlastní kủži, Lovci záhad, Úžasná tajemství vědy, Dobrodružství vědy a techniky, Horizont, Fascinující věda, Věda je náhoda, Hyde Park Civilizace aj. Výzkum V. Špačka z roku 2015 (Špaček, 2015) ukázal, že populárně vědecké pořady sleduje v televizi $35 \%$ dotazovaných a na internetu 35,7 \% dotazovaných. Mezi nejpopulárnější patří pořady Bořiči mýtů, Lovci záhad a Hyde park Civilizace. Zároveň ale $52,5 \%$ respondentů se domnívá, že je těchto popularizačních pořadů málo.

Bylo by těžké vyjmenovat všechny aktivity, které na podporu technického vzdělávání vyvíjejí jak stát, tak kraje a školy na všech úrovních vzdělávání. Je jasné, že zájem dětí o technické obory se musí začít vzbuzovat již od útlého věku (Babiš \& Havlíček, 2019). Ani zde nebylo nic zanedbáno, o čemž svědčí i rozsáhlé celorepublikové projekty financované z ESF, které probíhaly v ČR v letech 2012 až 2016 pod názvem Obsah, metody a formy polytechnické výchovy v mateřských školách a Studium učitelství pro MŠ jako dialog praxe s teorií.

Jedno je však jisté - školy na všech stupních vzdělávání by měly zatraktivnit obsahy technicky zaměřených předmětů, provést didaktickou transformaci obsahů tak, aby technické vědy byly spojeny se životem.

\section{Vliv popularizačních aktivit na zájem žáků o technické obory}

Cílem našeho dotazníkového šetření bylo zjistit dopad výše jmenovaných popularizačních aktivit na zájem žáků základních škol při volbě střední školy. V dalším textu se seznámíme s výzkumnými metodami a výzkumným vzorkem.

\subsection{Analýza současného stavu}

$\mathrm{Na}$ základě potřeb našeho šetření byla provedena analýza současného stavu popularizace technického vzdělávání na různých úrovních, od státu až po školu. Na tomto základě jsme přistoupili $\mathrm{k}$ další části - zjistit, jaký vliv tato popularizace má na cílovou skupinu - tedy na žáky základních škol - zda se zajímají o techniku, jaká je jejich představa při volbě zaměstnání, resp. při volbě střední školy

\subsection{Dotaznikové šetření}

Jako hlavní výzkumnou metodu jsme zvolili dotazníkové šetření. Pro potřeby našeho dotazníkového šetření byl vytvořen nestandardizovaný dotazník s několika položkami 
týkajícími se zájmu o technické obory a zároveň i volby střední školy. Také nás zajímalo, zda žáci sami vyvíjejí aktivity v oblasti technických věd, tzn., zda se zajímají o nové technologie, sami si vyhledávají informace z této oblasti, či zda sami sledují vědeckopopularizační pořady v médiích.

\subsection{Respondenti}

Respondenty byli žáci posledních ročníků základní školy. Celkem do výzkumu bylo zařazeno 180 žáků Plzeňského kraje.

\subsection{Realizace výzkumu, stanoveni hypotéz a sběr dat}

Základní výzkumnou otázkou je, zda žáci základních škol při volbě střední školy preferují školy technicky zaměřené a zároveň, zda žáci základních škol vykazují zájem o technické obory i ve svém volném čase, např. sledováním vědecko-populárních pořadů či čtením článků. $V$ našem výzkumu jsme se proto zaměřili na ověřování zájmu o technické obory, at' již při volbě střední školy, či v běžném životě. Hlavní hypotézu jsme mohli postavit tak, že $\mathrm{k}$ jejímu ověrení by postačila jednoduchá prezentace získaných dat. To by ovšem znamenalo, že data jsou prezentována jen s minimálním zamyšlením. Naším cílem ovšem analyzovat data podrobněji.

Základní hypotézu jsme stanovili pozitivně, nebot' budeme předpokládat, že vlivem různých aktivit a projektů bude zájem o technické obory veliký. Klíčový, pro sestavení hypotézy, byl zájem o technické obory - tedy předmět zkoumání. Tento zájem musí být ověřen $\mathrm{v}$ kontrastu se zájmem o jiné obory. Předpokládáme, že některé obory jsou atraktivnější než jiné, proto budeme zájem o technické obory porovnávat $\mathrm{s}$ nejpreferovanějšími. Pokud bychom vybrali pouze jeden nejpreferovanější obor, mohlo by se jednat o nestandartní výkyv, daný aktuálními faktory působící na tuto věkovou skupinu. Tak, abychom tento potencionální problém vyřrešili, budeme zájem o technické obory porovnávat s průměrem hodnot dvou nejoblíbenějších oborů. Limit oblíbenosti pak stanovíme na $2 / 3$ takto získané hodnoty.

\section{Základní hypotéza výzkumu:}

H1 - Průměrný počet preferencí výběru SŠ s technickým zaměřením (elektrotechnika, stavebnictví, strojírenství) dosahoval alespoň $2 / 3$ průměru preferencí dvou nejvíce preferovaných oborů.

Také budeme sledovat dílčí subhypotézy zaměřené na jednotlivé obory, tedy:

D H1 a - Celkový počet preferencí výběru SŠ s elektrotechnickým zaměřením dosahuje alespoň $2 / 3$ průměru preferencí dvou nejvíce preferovaného zaměření.

$>$ H1 b - Celkový počet preferencí výběru SŠ se stavebním zaměřením dosahuje alespoň $2 / 3$ průměru preferencí dvou nejvíce preferovaného zaměření.

$>\quad H 1$ c - Celkový počet preferencí výběru SŠ se strojním zaměřením dosahuje alespoň $2 / 3$ průměru preferencí dvou nejvíce preferovaného zaměření. 
Dále nás zajímal zájem o technické obory u žáků ve volném čase. Budeme předpokládat, že zájem o technické pořady a články, tedy jejich vyhledávání ve volném čase, je do určité míry spojen se zájmem o volbu technického oboru. V našem př́padě budeme zejména sledovat již výše zmíněné obory (elektrotechnika, stavebnictví, strojírenství). Budeme počítat $\mathrm{s}$ tím, že stejný zájem můžeme očekávat od př́buzných oborů, a to zejména informatiky a dřevařství a musíme též zohlednit neočekávaný zájem alespoň u jednoho oboru. Proto jsme hranici pro potvrzení hypotézy stanovili tak, že technické obory budou patřit mezi 6 oborů s největším mimoškolním zájmem.

> H2 - Žáci, kteří si volí školu technického zaměření (elektrotechnika, stavebnictví, strojírenství), vykazují vyšší zájem o technický obor než žáci, kteří volí ostatní obory.

\subsection{Ověreni hypotéz a prezentace výsledků}

$Z$ dotazníkového šetření jsme zpracovali data nejprve týkající se výběru středních škol. Tato data jsme následně analyzovali a ověrili jsme naši hlavní hypotézu pomocí dílčích hypotéz. Zde jsou prezentována data pro lepší přehlednost v grafické podobě.

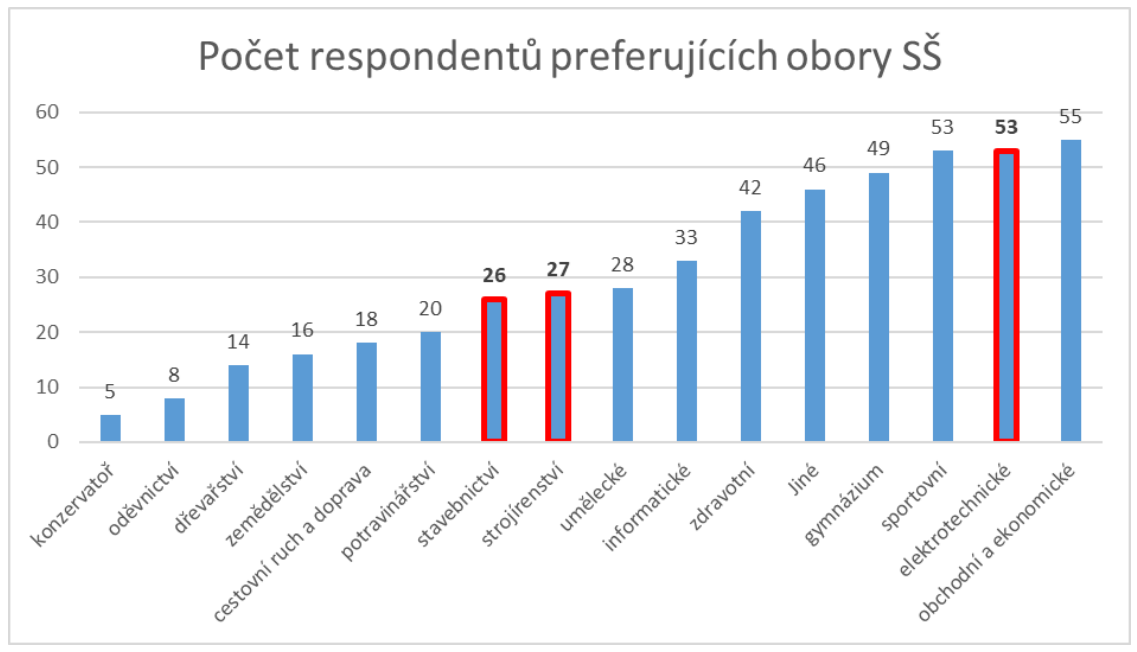

Graf č. 1: Počet respondentů preferujicich obory SŠ

Graf 1 znázorňuje preference devátých ročníků ve volbě zaměření střední školy. Můžeme vidět velký zájem o zdravotní, sportovní, elektrotechnické zaměření a gymnázium, největší zájem pak pozorujeme o školy zaměřené na obchod a ekonomiku. Mezi nejméně volené obory pak patří konzervatoř, oděvnictví, dřevařství, což může být dáno jejich specifickým zaměřením. $\mathrm{K}$ méně oblíbeným oborům můžeme přiřadit zemědělství, cestovní ruch, dopravu a potravinářství, což zároveň podporuje i všeobecné tvrzení, že o zemědělské obory není príiliš veliký zájem.

Nejprve jsme vypočítali skóre, které musí jednotlivé subhypotézy dosahovat. Výpočet průměru dvou nejoblíbenějších oborů byl následující: $55+53 / 2=54 . Z$ této hodnoty jsme 
ještě museli získat 2/3, jako hraniční hodnotu pro uznání subhypotéz: $54 * 2 / 3=36$. U všech oborů musí tedy preference žáků dosahovat alespoň počtu 36.

Ověření subhypotéz.

> H1 a - Celkový počet preferencí výběru SŠ s elektrotechnickým zaměřením dosahuje alespoň $2 / 3$ průměru preferencí dvou nejvíce preferovaného zaměření.

Celkem 53 žáků uvažuje o škole elektrotechnické, hraniční hodnota pro uznání hypotézy byla 36, subhypotéza byla tedy potvrzena.

> H1 b - Celkový počet preferencí výběru SŠ se stavebním zaměřením dosahuje alespoň 2/3 průměru preferencí dvou nejvíce preferovaného zaměření.

Žáků, kteří uvažují o studium v oblasti stavebnictví, bylo 26 , v této oblasti jsme tedy nedosáhli hraniční hodnoty, subhypotéza tedy byla vyvrácena.

> H1 c - Celkový počet preferencí výběru SŠ se strojním zaměřením dosahuje alespoň 2/3 průměru preferencí dvou nejvíce preferovaného zaměření.

Strojírenství jako potencionální výběr oboru SŠ označilo 27 žáků, tato subhypotéza byla vyvrácena.

Ověření hlavní hypotézy

> H1 - Průměrný počet preferencí výběru SŠ $s$ technickým zaměřením (elektrotechnika, stavebnictví, strojírenství) dosahuje alespoň $2 / 3$ průměru preferencí dvou nejvíce preferovaných oborů.

Hypotéza $\mathrm{H} 1$ byla vzhledem k malému zájmu o obory strojní a stavební vyvrácena: $53+26+27 / 3=35,33$. Pro potvrzení hypotézy bylo potřeba dosáhnout hodnoty 36 , hypotéza byla tudíž vyvrácena.

Dále jsme přistoupili k ověření hypotéz H2.

> H2 - Žáci, kteří si volí střední školu technického zaměření (elektrotechnika, stavebnictví, strojírenství), vykazují vyšší zájem o technický obor než žáci, kteří volí ostatní obory. 


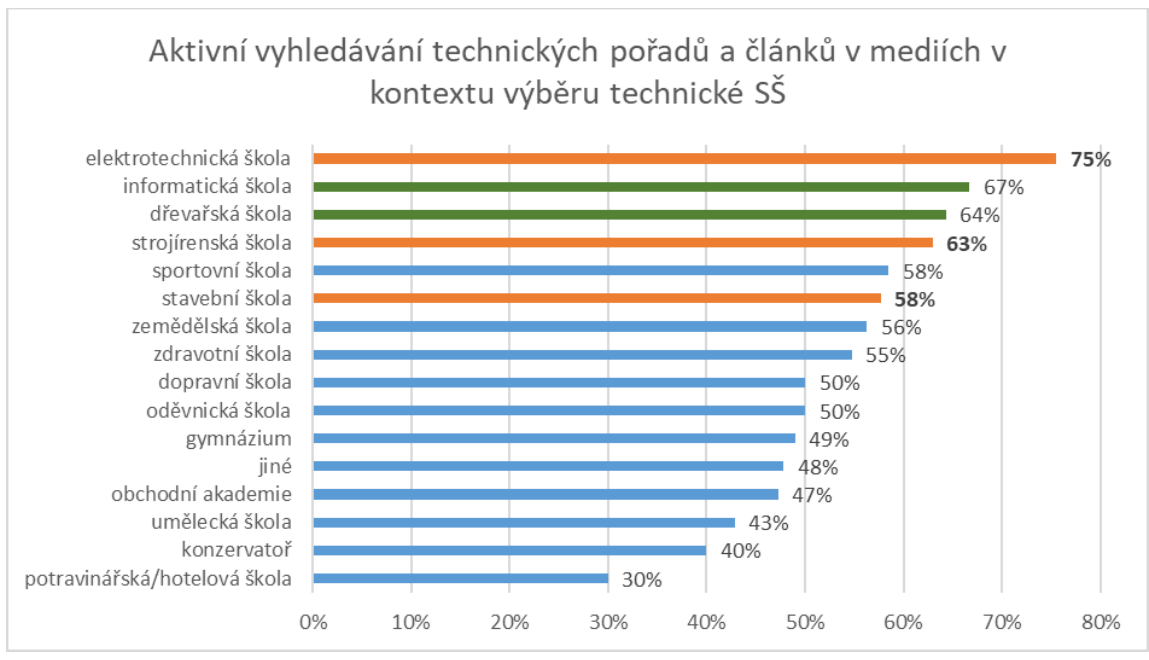

Graf č. 2: Vyhledávání technických pořadi̊ a článki̊ v kontextu výběru technické SS̆

Graf 2 znázorňuje, kolik procent žáků s preferovanými obory si alespoň někdy aktivně vyhledává technické pořady či články v médiích. Z grafu je patrné, že $58 \%$ žáků se zájmem o stavební obory, 63 \% žáků se zájmem o strojní obory a dokonce 75 \% žáků se zájmem o elektrotechniku si vyhledává technicky zaměřené články a pořady v různých typech médií. Překvapil nás poměrně velký zájem o technické články ze strany žáků, jež mají preferovaný obor sportovní.

Hypotéza $\mathrm{H} 2$ byla potvrzena. Žáci, kteří si vybírají školu s elektrotechnickým, strojírenským a stavebním zaměřením vykazují vyšší zájem o technické obory, nebot' patří mezi prvních 6 oborů seřazených podle zájmu o technický obor.

\section{Závěr}

Vzhledem $\mathrm{k}$ celé řadě propagačních aktivit a projektů ze strany státu, krajů a i samotných škol, které mají za cíl evokovat zájem o technické obory, jsme očekávali příznivější výsledky v oblasti zájmu o technické obory. Zájem o strojírenské a stavební obory bychom mohli označit dokonce jako podprůměrný. Mezi značně populární však patří elektrotechnický obor a informatika. Do jaké míry je zájem o technické obory ovlivněn podporou technického vzdělávání formou projektu či jiných popularizačních aktivit, je diskutabilní, nebot' tyto aktivity měly cílit na všechny obory technického zaměření. Otázkou zůstává, zda zájem o elektrotechnické obory a informatiku není spíše dán aktuálním rozvojem elektrotechniky všeobecně. Naším dalším výzkumným úkolem je analyzovat prŕíčiny tak malého zájmu o technické obory a nalézat východiska pro zvyšování tohoto zájmu již od počátku školní docházky. 


\section{Literatura}

Centrum robotiky. (2018). Retrieved January 24, 2019, from http://centrumrobotiky.eu/default/krouzky

Dostál, J. (2018). Podkladová studie. Člověk a technika. Praha: NUV.

Babiš, A.; Havlíček, K. (2019). Inovační strategie České republiky 2019-2030. Retrieved January 24, 2019, from https://www.vlada.cz/assets/mediacentrum/aktualne/III_Inovacni-strategie-CR_Country-for-Future_2019-01-

29_cistopis_white.pdf

Kopecký, M. (2007). V technice je budoucnost. Retrieved January 24, 2019, from https://anzdoc.com/v-technice-je-budoucnost.html

MŠMMT. (2013). Návrh nových opatření na podporu odborného vzdělávání. Retrieved January 24, 2019, from http://www.msmt.cz/vzdelavani/stredni-vzdelavani/navrhnovych-opatreni-na-podporu-odborneho-vzdelavani

Návratová, L. (n.d.). Moravskoslezský, Národní ústav pro vzdělávání. Retrieved January 24, 2019, from http://www.nuv.cz/p-kap/moravskoslezsky

NUV. (2015). Motivační programy pro žáky. Retrieved 2019, from http://www.nuv.cz/pkap/motivacni-programy-pro-zaky

NÚV. (2015). Podpora řemeslných a technických oborů aneb Co prozradí krajské akční plány. Retrieved January 24, 2019, from http://www.nuv.cz/p-kap/motivacni-stipendium Olomoucký kraj. (2015). Stipendia pro žáky technických oborů vzdělání zakončených maturitní zkouškou. Retrieved January 24, 2019, from http://www.krolomoucky.cz/stipendia-pro-zaky-technickych-oboru-vzdelani-zakoncenych-maturitnizkouskou-cl-1523.html

Pešková. (2015). Podpora odborného vzdělávání včetně spolupráce škol. Retrieved January 24, 2019, from http://www.nuv.cz/p-kap/podpora-odborneho-vzdelavani-vcetnespoluprace-skol

Pokorný, P. (2019). Rozvoj kariérového poradenství včetně prevence předčasných odchodů ze vzdělávání. Retrieved January 24, 2019, from http://www.nuv.cz/pkap/rozvoj-karieroveho-poradenstvi

RegionPlzen.cz. (2013). Kraj motivuje žáky ke studiu technických oborů. Retrieved January 24, 2019, from http://www.regionplzen.cz/zpravodajstvi/kraj-motivuje-zaky-kestudiu-technickych-oboru/

Bartošová, S.; Milota,L. Instituce na Plzeňsku ladí strategii na podporu technických oborů. Starostové a nezávislí. (2013). Instituce na Plzeňsku ladí strategii na podporu technických oborů. Retrieved January 24, 2019, from https://www.starostovenezavisli.cz/regiony/plzensky-kraj/aktuality/instituce-na-plzensku-ladi-strategii-napodporu-technickych-oboru

Špaček, V. (2015). Popularizace vědy v audiovizuálních médiích? Retrieved February 24, 2019, from https://www.vyplnto.cz/realizovane-pruzkumy/popularizace-vedy-v-av/ 